\title{
11. Informal Public Leadership: The Case of Social Movements
}

\section{David West}

\section{Introduction}

One form of public leadership often overlooked by scholars is that of politically engaged parts of society, in particular, social movements. In fact, even within the social movement literature, the role of leaders(hip) is under-theorised. This chapter makes a small contribution to plugging these gaps. I focus on some of the contrasts between leadership in formal institutional or organisational contexts and leadership within the less organised, less institutionalised context of social movements (SMs). There is, however, considerable overlap between the nature of leaders and leadership in these different contexts. SM leadership is not entirely different from forms of leadership in more institutionalised contexts, if only because social movements do include organisations and often interact with political institutions. The distinctive nature of SM politics means, further, that SM contexts themselves cannot be demarcated as clearly institutional ones. The context of SM leadership always tends to extend beyond the movement and its membership to the broader public sphere and society. If anything, distinct constituencies of movement support, which might define the boundaries of ' $a$ ' movement, are products, rather than premises, of SM politics and leadership. For these reasons, the study of SM leadership cannot be isolated from the study of leadership more broadly.

\section{Social movements as partially, non- or extra-institutional forms of politics}

Social movements can be defined as non- or extra-institutional forms of politics, occurring within the sphere of 'civil society'. Jan Pakulski defines social movements as 'recurrent patterns of collective activities which are partially institutionalised, value oriented and anti-systemic in their form and symbolism'. (1991: xiv). Though they typically include, are associated with, or give rise to organised groups and formal organisations, SMs are both broader and more diffuse than their organisational manifestations. The green movement is, for example, more than the sum of associated organisations such as Greenpeace, the Australian Conservation Foundation, World Wildlife Fund or green electoral parties. Again, SMs often aim to bring about changes at the level of formal political institutions, but they need not be exclusively concerned with institutional changes and sometimes by-pass institutional politics altogether. 
Although it is difficult to characterise the relationship between SMs and institutional politics in general, yet still precise, terms, it is intuitively helpful to understand that SMs as primarily concerned with the formative dimension of politics. Where institutions and organisations reflect existing interests and social divisions, SMs are typically concerned with emerging issues, values, identities and constituencies. Institutional reforms and new organisations may come about as a result, but the movement as such cannot be reduced to its institutional manifestations and consequences. Alain Touraine describes social movements in quasi-volcanic terms: 'Men make their own history: social life is produced by cultural achievements and social conflicts, and at the heart of society burns the fire of social movements.' (Touraine 1981: 1)

Imagery apart, it is significant that social movements imply conflict. Social movements are not only extra-institutional, they are also anti-systemic, challenging current institutions or 'the system' from outside. SMs typically occur where institutions are judged to have failed, or to stand in need of reform or even revolutionary change. At the same time, SMs are not necessarily anti-institutional in the sense of being opposed to all (rather than just existing) institutions. However, an anti-institutional or quasi-anarchist orientation has been a significant element in some recent movements. Further complications arise from the fact that anti-systemic movements often provoke 'conservative' or 'reactionary' movements, which defend the status quo against these 'radical' or 'progressive' challengers.

The complex relationship between SMs, organisations and institutional politics results in a similarly complex relationship between what I shall refer to as 'formal' and 'informal' models or, in Weberian terms, 'ideal types' of leadership. Formal leadership occurs within conventionally institutionalised political contexts government, public service, judiciary - as well as in formally constituted organisations - political parties, interest groups, lobby groups, trade unions etc. The formal model of leadership is compatible with an overall view of a hierarchy of levels of leadership from smaller and more local to larger regional, national and global contexts. By contrast, informal leadership occurs essentially outside of such contexts. It is particularly relevant to SMs, although it should be clear that issues of formal leadership still arise both within movement organisations and in their relations with political institutions.

This chapter concentrates on some consequences of the informal nature of (much) social movement leadership. As a secondary issue, it will consider some implications of the actual situation of SMs, which involves a complex interaction between institutional and extra-institutional, formal and informal, fully constituted and formative dimensions of politics. 


\section{Extra-institutional sources of leadership}

Institutional leaders have whatever power and authority they have, at least in part, by virtue of their office. In contrast, SM leadership involves acting without a recognised institutional position or office. In Weber's terms, SM leaders cannot rely on either 'traditional' or 'legal-rational' authority, but have to create their authority by means of charisma (Weber 1947: part III, $324 \mathrm{ff}$ ). Charisma refers to those personal qualities of a leader that inspire loyalty and recognition from followers: 'It is recognition on the part of those subject to authority which is decisive for the validity of charisma' (Weber 1947: 359). In the absence of traditional, routinised or rule-based institutions and obligations, charisma has the capacity to generate 'new obligations' (361). Charismatic leadership has often been based on religious, mystical, emotional and other seemingly 'irrational' forms of appeal. This is particularly clear for religious and religio-political leaders (of particular interest to Weber) such as the Jewish 'Messiah', Muslim 'Mahdi' or Christian revivalist. Unlimited by either traditional, legal or rational constraints, charismatic leadership readily assumes authoritarian form and is associated with violent social upheaval and, in the twentieth century, fascism.

However, more pertinent to the recent experience of SMs is a variant of charismatic authority qualified by moral constraints. Although the category of 'new' social movement (NSM) is contested and problematic, it does serve to highlight prominent features of the upsurge of SM activity from the 1960s (for example, Jennett and Steward 1989, Dalton and Kuechler 1990). SMs, like second-wave feminism, gay and lesbian liberation, environmentalism and the peace and anti-nuclear movements largely avoided violence and revolutionary insurrection. In place of a conflictual and state-centred politics of class interest and material advantage, they pursued an 'identity politics' of moral and cultural contestation. They favoured a 'pre-figurative' politics, which seeks to align present political means with future political goals. Accordingly, traditions of non-violent direct action and civil disobedience, which involves violating current norms of institutional legitimacy (i.e. laws) by means that are yet morally defensible (Singer 1973), played an important role.

The morally constrained variant of charisma appropriate to NSMs is illuminated with the help of John Kane's notion of moral capital, which refers to 'the part played in political contexts by people's moral perceptions of political actors, causes, institutions and organisations' (2001: 4). Moral capital is an important political resource of formal leaders, 'one that in combination with other familiar political resources enables political processes, supports political contestants and creates political opportunities' (Kane 2001: 2). But moral capital is something that also originates, and can be created outside of existing political institutions in informal leadership contexts. Kane discusses Nelson Mandela and Aung San Suu Kyi as two leaders who deployed moral capital in the cause of dissident 
politics. Moral capital is also a key resource of the movement as a whole in its promotion of new identities, communities of interest and, ultimately, social and cultural change.

Crucially, a dissident politics of moral challenge and moral capital implies corresponding limits on the goals and tactics that can be adopted by the movement - a feature, as already noted, of pre-figurative styles of politics favoured by NSMs. Of course, any moral limits will depend on prevailing moral norms and on the public's perceptions and judgments. But although moral norms may be culturally and historically variable, they are not infinitely malleable or meaningless. At the same time, a significant goal of SMs is the reinterpretation and transformation of prevailing values and norms. For example, the gay movement seeks to extend liberal values of privacy and freedom concerning self-regarding actions to sexual conduct. Anti-racism and feminism advocate more consistent and inclusive values of equality and fairness. The politics of moral capital seem particularly suited to such goals.

NSMs have succeeded in transforming broader norms of legitimate political conduct as well. Before the 1960s, liberal democrats routinely denied legitimacy to all extra-institutional movements and challengers, maintaining that advocates of change should vote in elections, petition leaders and officials, form new political parties or put forward their arguments in the public domain. From this perspective, SMs were regarded as disorderly threats to political stability along with mobs, riots and panics - examples of what was derogatively termed collective behaviour. The rise of the 'new' movements rehabilitated extra-institutional forms of politics so that SMs can now studied as potentially rational forms of collective action (Della Porta and Diani 1999). SMs can be understood, not as irrational 'outbursts' or 'eruptions' of pent-up frustration, but as the rational achievement of collective action on behalf of previously neglected or excluded issues and groups. This understanding of SMs provides the context for the following discussion of informal leadership.

\section{Three dimensions of social movement leadership}

The following explores three salient features of ideal-typical SM leadership.

\section{Leaders, followers, actors}

It has been widely observed that leadership depends on the correlative role of followers or 'followership'. Particular leadership qualities reflect complementary tendencies of followers to approve or respond appropriately to those qualities (Burns 1978; Little 1985). But the relationship between leaders and followers is significantly qualified in the informal context of social movement politics. In part, this results from what we have described as the formative nature of social movement politics. Since a SM does not have a pre-existing constituency or 
membership, the first task of SM leadership is to encourage people to become followers, to identify themselves as members of a movement (cf. B below).

The recent context of 'new' social movements further qualifies the leader-follower relationship through the widespread suspicion of leadership associated with the 'new' politics. Of course, formal and even strikingly hierarchical organisations have played a prominent role in some contemporary movements - Greenpeace is an example familiar from the green movement. But more distinctive of NSMs is a suspicion or even hostility toward hierarchy and leadership. The 'affinity' groups of the May 1968 Events in Paris, the 'consciousness raising' groups of second-wave feminism and anarchist elements of the anti-globalisation movement limit or dispense altogether with leadership roles on principled grounds (Bookchin 1974; Rowbotham 1979). Also influential was the New Left, which canvassed criticisms of Soviet 'democratic centralism', bureaucratic labour organisations and Leninist parties of 'activists' charged with 'organising' the masses of workers and peasants. Strong leadership and hierarchical organisations were, in other words, implicated in the authoritarian politics of 'actually existing socialism'.

The 'new' movements sought to avoid the authoritarian fate of the Old Left by encouraging more active and widespread involvement of members. A fully active membership will better be able to control leading figures of the movement. Active members will also be 'empowered' - gaining confidence as well as technical and political skills - through their involvement (West 1990). Rather than being a passive 'constituency' or interest group 'represented' by its leaders, members of SMs are therefore more accurately described as actors or agents. Not passive 'followers', these actors are the true bearers of the movement. Indeed, in contrast to formal organisations and institutions, a social movement can only be said to exist at all to the extent that there is an ongoing and widespread pattern of collective activities. 'Subject group' may be a more appropriate term to refer to the collectivity of actors constituting the movement (Laclau and Mouffe 1985).

The more active role of movement participants has implications for the relationship between leadership and representation. If the representative acts not only on behalf but also instead of those she represents, representation substitutes for, rather than complements the active involvement of movement actors. Deleuze and Foucault speak in this context of the 'indignity of speaking for others' (Foucault and Deleuze 1977). In fact, SM leaders (and organisations) have been criticised, because they are unable to make binding commitments on behalf of their 'followers' (Offe 1985). But this is to misunderstand the relationship between movement leaders and participants in terms more appropriate to the context of formal representative organisations. What is more, the strength of a movement may be increased, when its actions cannot be easily controlled or predicted. Movement leaders may be co-opted by the 'system', 
but they are less able than their institutional counterparts to 'deliver' the movement as their part of any bargain.

It follows that informal leadership will require different qualities (or a different weighting of qualities) than is the case in formal leadership contexts. SM leadership implies, for example, the ability to 'inspire', 'activate' and 'empower' rather than qualities of decisiveness or authoritative command. Military qualities and corresponding metaphors of 'militants' and 'mobilisation' are inappropriate. The institutional leader may be able to decide when to order his followers to act; electoral parties are only periodically concerned with attracting and 'getting out' votes in electoral contests. By contrast, SM leadership is always concerned, first and foremost, with generating and maintaining participant activity.

Significantly, SM leaders also aim to inspire actions with a greater degree of autonomy and initiative than in formal contexts. Hierarchical organisations have typically valued obedience, loyalty, solidarity and, at the extreme, the sacrifice of individuality and autonomy for the sake of the cause (cf. Arendt 1952/1958; Koestler 1950). The strength of movement, on the other hand, is increased when actions proliferate both numerically and qualitatively as a result of the plurality of relatively independent centres of thought and decision. Change may occur less through a unified course of action imposed from above than from a 'contagion' of actions and reactions (Guattari 1984). On the other hand, this contagious quality also represents a challenge for SM leaders. Cascading political actions may violate the moral norms - and so diminish the moral capital - on which the broader authority and impact of the movement relies (Philp 2007: ch. 8).

A deeper investigation might consider how the to-us-familiar opposition of 'leader' and 'followers' serves to distort our understanding of political action. According to Hannah Arendt, the ancient Greek understanding of action acknowledged the differing roles of 'leader' and 'followers' without obscuring their interdependence in an essentially cooperative enterprise. This recognition has been lost in the subsequent evolution of our political vocabularies (Arendt 1958: 189; 2005: 45). Something like Arendt's more cooperative understanding of action is particularly relevant to the experience of contemporary social movements. Indeed, renewed focus on social movements brings us closer to the 'original' understanding of action.

\section{Moral, cultural and ideological innovation}

The nature of SM leadership is further qualified by the role of creativity and innovation in social movements. Social movements, as we have seen, are not concerned so much with the pursuit of existing interests or issues as with the emergence of new interests and issues, new political identities and cultural patterns. 
There is a problem, therefore, with theoretical approaches premised on fixed assumptions about interests and motivation. For example, rational choice approaches such as 'resource mobilisation theory' portray the task of SM leadership as predominantly concerned with the organisation of political resources and incentives in order to mobilise self-interested utility-maximisers with a given array of interests. The leader is a political 'entrepreneur' searching for new (political) market opportunities (Taylor 1982). Whilst their conclusions may be valid within the limits of their own assumptions, such approaches neglect the essentially creative role of SM leadership. Rather than simply 'packaging' existing interests and resources into more politically potent combinations, SMs succeed by transforming interests and identities.

The creative demands of SM leadership require a different range of leadership qualities. Ideological and cultural innovators play a significant role in SMs. SMs leaders flourish, accordingly, on the basis of rhetorical skills, moral suasion and cultural inspiration as much as organisational skills or decision-making. By implication, too, there are diffuse boundaries between SM politics and other areas of social life, such as the arts, cultural activities and even science. A work of literature or philosophy may make a crucial contribution to the emergence of a SM. This helps to explain the acknowledgement of a writer like Oscar Wilde as a leading figure of the gay movement, Frantz Fanon as an icon of anti-colonialism, or Germaine Greer and Shulamith Firestone as leading feminists. Scientific ecology and other sciences have played a similarly important role in the rise of 'green' and environmental movements. The porous boundaries of politics and the political reflect the particular role of SMs as significant agents of politicisation, which involves transgressing these boundaries.

\section{Social movements and the public sphere}

The porous borders of politics are also manifested in the relationship of social movements and SM leaders to the public sphere. SMs obviously have an important relationship to the emergence of the modern 'public sphere' in western societies. Both SMs and the public sphere rely on and reflect key dimensions of 'modernity' - including industrialisation and urbanisation, expansion of printing and news media, improving means of transportation and communication. Both develop in complex interaction with parliamentary politics and broader processes of democratisation (Tilly 1978).

But SMs should also be recognised as active agents in the formation of the public sphere, not simply as players within it. The democracy movements in communist Eastern Europe before 1989 can be understood, in this way, as laying the foundations of a previously non-existent (or fragmentary) public sphere and civil society (Keane 1988). Even in liberal democracies with established civil societies, NSMs have broadened the agenda of public discussion along a number of dimensions. Previously neglected issues and constituencies - relating to 
gender, sexuality, racism, peace and the environment - have been introduced to the public sphere as a result of their activities since the 1960s. NSMs have contributed to the increasing complexity and responsiveness of the public sphere - or, more accurately perhaps, they have contributed to the proliferation of a plurality of public spheres (Habermas 1981; Fraser 1997).

The relationship of social movement and public sphere(s) has implications for informal leadership. The public role of SMs means that they and their leaders never simply address a confined constituency of 'members' or 'supporters'. They must always strive to reach across the boundaries of their 'subject group' to a wider public of potential participants and supporters. Even opponents are an important 'counter-constituency', especially when movements represent nominally minority interests and so must depend on their support or, at least, acquiescence. The complexity and heterogeneity of the 'audience' of SM leaders means there will often be tensions between public and 'movement' responses to particular statements or actions. The public context of SMs means, finally, that the movement as a whole itself exercises a kind of leadership role within the wider society.

\section{Interactions between institutional and social movement leadership}

It has already been noted that informal SM leadership will rarely exist in 'pure' or 'ideal typical' form, because SMs are almost always involved with movement organisations and political institutions. But if SM leadership rarely occurs in pure form, it is also true that formal institutional leadership, in its turn, seldom lacks a 'social movement dimension' entirely. The following are a few relevant observations on interactions between formal and informal leadership contexts.

Social movements are, in practice, more or less closely related to the broader institutional and organisational terrain. Leaders sometimes derive their initial authority within the movement in part, at least, from their pre-existing institutional leadership positions. A perhaps minor formal or institutional position can sometimes be translated into a much expanded role within the movement. Religious office often plays this role: Martin Luther King, for example, was a minister of the church before he rose to a position of leadership in the Civil Rights Movement. Conversely, of course, SM leaders often take up positions within the institutional sphere. In Australia, Peter Garrett and Bob Brown offer contrasting lessons of the difficulties and opportunities involved in the transition from the green movement and its associated organisations to formal positions of leadership.

More generally, formal institutional leaders will also depend on qualities associated here with informal leadership. We have already mentioned Kane's exploration of ways in which institutional leaders are reinforced or undermined 
by their moral capital or lack thereof. He considers the contrasting cases of Nelson Mandela, John F. Kennedy and Richard Nixon (2001). The 'Machiavellian' dilemmas faced by political leaders, who try to reconcile effectiveness in the 'real world' (or 'realism') with moral principles ('idealism'), inevitably tend to erode their moral capital in the long run. In contrast to social capital which, according to Robert Putnam, increases the more it is used (Putnam 1993: 169), the use of moral capital does tend to use it up. The durability of formal leaders, their ability to maintain appeal and authority over time, therefore depends on their ability to manage this problem. To achieve this may require qualities more often associated with informal leadership - qualities, for example, enabling formal leaders to revive their support and/or extend their appeal beyond existing constituencies.

Evidently, the same Machiavellian dilemmas also afflict social movements and informal leadership. Partly as a result, the successful institutionalisation of a movement - the translation of its demands and values into political influence, legal and institutional recognition, party formation and even government - is not infrequently associated with the decline or disappearance of the movement as a movement. Institutional manifestations of a SM readily fall victim to the same contradictions between ideal values and political expediency besetting conventionally institutionalised politics. Leaders faced with difficult policy dilemmas are tempted to sacrifice long-term movement ideals for the sake of immediate practical gains. Drawn into the orbit of institutional politics and tempted by the rewards of office, leaders may be 'co-opted' by the 'system'. Movement participants may feel 'betrayed' by their co-opted leaders. Perceptions of institutional recognition and satisfied demands may, in any case, encourage participants to withdraw from active involvement in the movement.

A prominent example of the price paid by a SM for institutional success is the nineteenth-century working-class movement, which gave rise to, but then was effectively replaced by its institutional offspring of trade unions, labour and social democratic parties and welfare state. The demise of the working-class movement in its revolutionary incarnations has been even more stark. Of course, some substantive gains resulted from the institutional successes of the movement - the welfare state in capitalist liberal democracies and some equivalent social protections in the former communists states. But since the 1970s at least, the welfare state has, in the absence of a strongly persisting social movement, proved vulnerable to neo-liberal counterattack. The dramatic collapse of 'actually existing socialism' after 1989 led, by an even more direct route, to harsher versions of liberal capitalism.

The mixed outcome of the working-class movement's 'successful' institutionalisation provided important, formative lessons for 'new' social movements. One of the most distinctive features of NSMs has been their 
self-consciously critical or cautious orientation towards institutional politics and the attempt to avoid such negative outcomes. NSMs have sought to achieve changes beyond and, to some extent, independently of the institutional political sphere - changes in identity, culture, consciousness, consumption and so on. When these movements have nevertheless sought institutional reforms, they have done so with the intention of preserving high levels of movement activity. The German Green Party is the most well known example of an organisation designed to pursue the benefits of institutionalisation without exhausting the transformative force of the underlying movement. The Greens were formed, in this sense, self-consciously as an 'anti-party' or 'movement' party. Their qualified successes in this regard only confirm the difficulties involved in truly achieving this goal (Hülsberg 1988).

More broadly, the fragility and enduring value of social movements are important themes in the renaissance of SM studies since the 1970s. These studies support the view of social movements and civil society as permanent and essential elements of any genuine, as opposed to merely formal or nominal, democracy (Keane 1988; Cohen and Arato 1992). By the same token, leaders and movements attempting to satisfy the 'hybrid' demands of both formal and informal political contexts face a complex and daunting task.

\section{References}

Arendt, H., 1952, The Origins of Totalitarianism, London: Allen \& Unwin.

Arendt, H., 1958, The Human Condition, Chicago and London: University of Chicago Press.

Arendt, H., 2005, The Promise of Politics (ed. Jerome Kohn), New York: Schocken Books.

Bookchin, M., 1974, Post-Scarcity Anarchism, London: Wildwood House.

Burns, J. M., 1978, Leadership, New York and London: Harper \& Row.

Cohen, J. and A. Arato, 1992, Civil Society and Political Theory, Cambridge, MA: MIT Press.

Dalton, R. J. and M. Kuechler, 1990, Challenging the Political Order: New Social and Political Movements in Western Democracies, New York and Oxford: Oxford University Press.

Della Port, D. and M. Diani, 1999, Social Movements: An Introduction, Oxford and Malden, MA: Blackwell.

Foucault, M. and G. Deleuze, 1977, 'Intellectuals and Power' in Language, Counter-memory, Practice, trans. D. F. Bouchard and S. Simon, Ithaca, NY: Cornell University Press. 
Fraser, N., 1997, Justice Interruptus: Critical Reflections on the 'Postsocialist' Condition, London and New York: Routledge.

Guattari, F., 1984, Molecular Revolution: Psychiatry and Politics, trans. R. Sheed, Harmondsworth: Penguin.

Habermas, J., 1981, 'New Social Movements', Telos, 49, pp. 33-7.

Hülsberg, W., 1988, The German Greens, trans. G. Fagan, London and New York: Verso.

Jennett, C. and R. G. Stewart, 1989, Politics of the Future: The Role of Social Movements, Melbourne: Macmillan.

Kane, J., 2001, The Politics of Moral Capital, Cambridge and New York: Cambridge University Press.

Keane, J. (ed.) 1988, Civil Society and the State: New European Perspectives, London and New York: Verso.

Koestler, A., 1950, Darkness at Noon, trans. D. Hardy, London: Cape.

Laclau, E. and C. Mouffe, 1985, Hegemony and Socialist Strategy: Towards a Radical Democratic Politics, London and New York: Verso, 1985.

Little, G., 1985, Political Ensembles: A Psychosocial Approach to Politics and Leadership, Oxford and New York: Oxford University Press.

Offe, C., 1985, 'New Social Movements: Challenging the boundaries of institutional politics', Social Research, 52:4, pp. 817-68.

Pakulski, J., 1991, Social Movements: The Politics of Moral Protest, Melbourne: Longman Cheshire.

Philp, M., 2007, Political Conduct, Cambridge, MA and London: Harvard University Press.

Putnam, R. D., 1993, Making Democracy Work: Civic Traditions in Modern Italy, Princeton, NJ: Princeton University Press.

Rowbotham, S., 1979, 'The Women's Movement and Organizing for Socialism', in S. Rowbotham, L. Segal and H. Wainwright (eds), Beyond the Fragments, London: Merlin Press.

Singer, P., 1973, Democracy and Disobedience, Oxford: Clarendon Press.

Taylor, M., 1982, Community, Anarchy and Liberty, Cambridge and New York: Cambridge University Press.

Tilly, C, 1978, From Mobilization to Revolution, Reading, MA and London: Addison-Wesley.

Touraine, A., 1981, The Voice and the Eye: An Analysis of Social Movements, Cambridge and New York: Cambridge University Press. 
Public Leadership-Perspectives and Practices

Weber, M., 1947, The Theory of Social and Economic Organization, New York: Free Press.

West, D., 1990, Authenticity and Empowerment: A Theory of Liberation, Hemel Hempstead: Harvester Wheatsheaf. 